\title{
Opportunities for Foreign Investments in the Economy of Kosovo
}

PhDc. Rifat Hoxha ${ }^{1}$

\author{
Prof. Ass. Dr. Hamdi Hoti² \\ MA. can. Edisona G. Kurhasku³ \\ ${ }^{1}$ Faculty of Economics, University of Prizren, rifati_pz@hotmail.com \\ 2Faculty of Economics, University of Prizren, hamdi_hoti@hotmail.com \\ 3Faculty of Economics, University of Prishtina, edisonakurhasku@gmail.com
}

Doi:10.5901/mjss.2016.v7n3p185

\section{Abstract}

Foreign investments are of great importance in the economic development of the country. For the economy of any country, especially those in transition, such as the Balkan countries, and especially Kosovo, followed by the effect of foreign direct investment. Fragile economies are more volatile and dependent on foreign investment. Economic development opportunities of foreign investment in the economy of these countries are very large. The process of foreign investment is accompanied by many challenges. Therefore, analysis of the paper presents a general outline of economic development, the effects of foreign direct investment in Kosovo, improving the investment environment, opportunities and challenges in the future, and finally provides a summary of recommendations.

\section{Introduction}

Kosovo is undergoing significant construction period the state not only politically, but in the development and strengthening of the economy in general. Economic development and growth for the country's welfare is the primary goal. Foreign investments play an important role in this process. In Kosovo, these investments are necessary. Paper made a fundamental analysis of the field of foreign investment, to analyze their impact on the economy, and the challenges and opportunities for foreign investment. FDI is considered as an important mechanism in the development of a country's economy. Therefore, the paper aims to present a summary analysis of investments in the field of Kosovo to produce economic indicators that show the development of these investments and analyze current challenges and improve the economic and legal environment for investment in the future.

\section{Economic Development of Kosova}

In the last decade of the twentieth century, the Western Balkan countries have experienced the bitter rivalry of political and economic. After these rivalries, they have joined in a European political perspective and grouped together for sustainable economic development. Kosovo is part of the Western Balkan countries.

By the end of XX century and the beginning of the XXI Century, Kosovo has gone from a country with centralized economic status (centralized economy) in a country that is aspiring to adopt the principles of free market economy. Among the main challenges in this process is the prospect of economic development and its relation to the welfare of citizens in Kosovo. Economic development and sustainable economic growth in Kosovo are the main strategic goals and priorities. These goals and strategic priorities are foreseen in the Action Plan of the Economic Vision of Kosovo 20112014 (Primeminister, 2011-2014). This plan has identified a number of factors (Primeminister, 2011-2014).

Affecting the economic development of Kosovo, such as:

$\checkmark$ Maintaining macro stability;

$\checkmark$ Investments, investment environment and private sector support;

$\checkmark$ Development of public infrastructure;

$\checkmark$ Development of human capital.

Important factor in economic development in the country are foreign investments.

The initial steps of economic development have gone through various challenges and processes. Economic processes from mid-1999 until today, have evolved gradually in time and different perspective and foreign investments 
have had a positive impact on the overall development in Kosovo. International reports estimate a satisfactory level of economic development, but in some tough areas give recommendations related to the rule of law (group, 2016). Although challenges still remain. Economic data below reflect the economy of Kosovo is yet to be formed and developed more. Important prerequisite for the economic development is the improvement of the investment environment and economic sustainability. Kosovo is currently no satisfactory basis for environmental legislation of foreign investment and economic development.

By World Bank data shows that the environment of economic development and investment in Kosovo has progressed satisfactorily despite occasional fluctuations (group, 2016).

World Bank Group states that "reforms of doing business in 2014 are characterized by the procedures of starting a business, obtaining construction permits and registering property" (Bank, 2016). The data show an increase in economic activity compared with previous years. This is partly related to the positive development of the euro area economy (EU) and is reflected as a result of increased remittances (money remittances) (Kosovo, September 2014). The possibilities of further development of the economy to foreign direct investment are enormous, but the whole process of foreign investment was followed by many challenges. So it reflects the positive development of the economy of Kosovo during these years are some principles, rules and institutions that have developed and aim to increase the sustainability of economic development and gradual.

\section{The Impact and Effects of Foreign Direct Investments in Kosovo}

FDI capital construction include the transfer of financial, construction technology and other abilities (management, membership marketing, accounting), FDI plays an important role in transforming countries, especially those postcommunist.

On changing the structure, and opening understands economic progress both on international and competitive advantages in orientation and international cooperation, such as the countries of CEFTA. One of the advantages of FDI is that they help in the economic development of the country where the investment flow. FDI membership also allows the transfer of technology, which has been done in such a way to secure capital inputs. Countries that have received FDI from another country develop physical- of their human resources, hiring new people Chat in any business activity membership. FDI to assist with membership in the creation of new labor, wage growth, hand in facilitating livelihoods livelihoods, etc. FDI membership are a source of financing the deficit in the Balance of Payments improving its lending in host countries (Moosa, 2002). Although FDI benefits from membership in the host countries are widely accepted in a positive way. Author, Brewer (1993) argues that there is a conflict between the interests of enterprises and those membership multina- host countries.

Enterprises require many-nationals three main conditions:

$\checkmark$ Production possibilities that are cost effective solutions;

$\checkmark$ Sale where prices are more high;

$\checkmark$ Repatriation takings in the country of origin.

On the other hand, the host country requires membership maximiles his benefits for the economy, which requires investment possibly to still many more to obtaining membership of retention of foreign enterprises in the country (Brewer, 1993).

FDI membership in itself contain higher construction costs membership communication, travel, etc. Linguistic and cultural differences that exist between the investing country and the host country, may also pose problems in the case of FDI. However, a disadvantage of FDI is that there is a possibility of failure in a company owned and that there are companies out. This has made many companies that often t iu FDI approach with a high membership care. Two different approaches to the effects of FDI in host countries were analyzed by the authors Hood and Young 1979. Firstly, the most important benefits to the host country direct from FDI upward from higher income from taxes. Secondly, the absence of perfect competition may be the reason that the cost advantages of multinational enterprise to be higher in a country other than the host country (Hood, N. and Young, S, 1979). In the case of Kosovo, as the effects of foreign direct investment, FDI has created jobs directly and indirectly to suppliers and partners, have had a significant impact on increasing investment in domestic companies have raised overall productivity have intensified competition in the market, creating an incentive for innovation, and pay higher wages they have a multiplying effect on earnings.

\section{Foreign Direct Investment in the Economy of Kosovo}

Given the advantages created, such as the system of excellent taxes, abundant natural resources, registration quick and 
easy business, transparent laws on foreign investment and other advantages, make Kosovo an attractive environment favorable for investors foreign.

As a result, Kosovo has attracted over $€ 1.5$ billion of foreign direct investment.

The flow of FDI in the years 2006-2013 in Kosovo

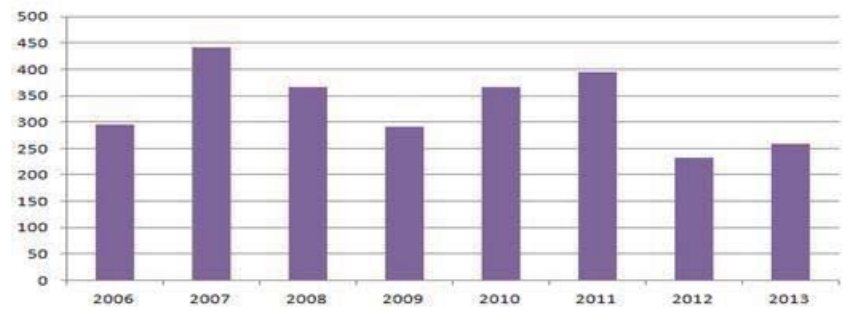

As a result of the privatization process, in $2007 \mathrm{FDI}$ had an increase of 440 million $€$ of FDI, and as a result of the global financial crisis, FDI has decreased continuously since 2008, while in 2013 was marked improvement this indicator from $4.7 \%$ to $5.0 \%$.

Besides investment pioneers as Raiffeisen Bank and ProCredit, who entered the Kosovo market in the early phase of transition, there are many other foreign companies engaged in a wide range of business sectors.

According to the Registry of business so far, there are about 4,000 companies of foreign ownership and mixed that have already used the opportunity to invest in Kosovo. The large number of foreign companies operating in Kosovo is a testimony to the opportunities and benefits that the country offers. As shown in the figure below Foreign direct investments in real estate have increased dominance in the structure of total FDI during 2013. The increase is also characterized by the transport sector and telecommunications, financial services, energy and trade, while FDI of the construction and manufacturing sector have decreased in the structure.

\section{FDI by main economic sectors, in percentage}

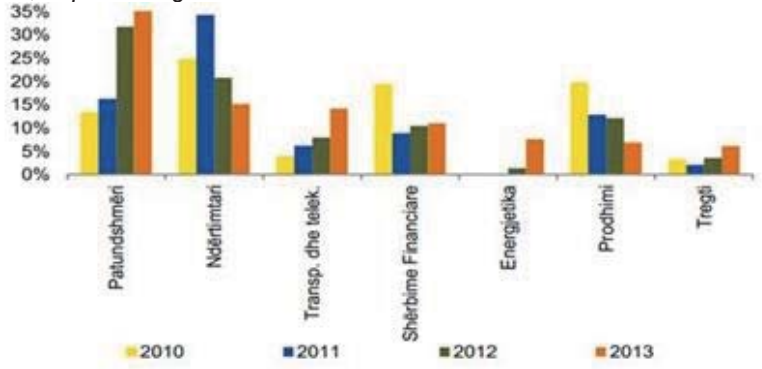

Source: CBK 2014

In 2013 the real estate sector had increased 35\%. Another important sector was the transport and telecommunications sector growing 15\%, then $12 \%$ financial services, energy trade $7 \%$ and $5 \%$. Regarding the origin of FDI, Turkey represents the country whence the bulk of investments $33.6 \%$, Switzerland $16.1 \%$, Germany $8.4 \%, 7.9 \%$, etc. Albania. Investment from Turkey have increased by $32.3 \%$ during 2013, investment from Germany and Switzerland had decreased to $4.8 \%$. Therefore it is worth noting that investments in Albania have tripled in 2013 compared with 2012 (Bank K. C., 2012, ).

\section{Economic Development Opportunities, Foreign Direct Investment}

Taking into account some of the facilities offered and the favorable sectors for FDI analyzed above, Kosovo constitutes a favorable climate for doing business and also for FDI. Taking into account the potential that is trying to provide for the sustainable improvement of the macroeconomic environment and the possibility of FDI in different sectors of the business, it can be concluded that Kosovo has great potential to attract FDI. The interest of foreign direct investors is 
associated with many other requirements relating to the safety and protection of foreign investments.

A very important development in this regard in terms of growth opportunities for economic development by foreign investment constitutes Law Nr. 04 / L-207 on the Ratification of the Framework Agreement between the Government of the Republic of Kosovo and the European Investment Bank regulating the activities of the European Investment Bank in Kosovo (Kosovo G. 0.). This law aims to make the framework agreement which allows the EIB (European Investment Bank) to extend funds to projects that are significant for the development of the competitiveness of Kosovo and to support the development of Kosovo by giving perspective clear.

This agreement allows the bank to fund projects in Kosovo, especially in the areas of:

$\checkmark$ Environment

$\checkmark$ Transportation

$\checkmark$ Telecommunications and energy infrastructure,

$\checkmark$ Provide technical support that is focused on the preparation and financing of priority projects which are important for the development of Kosovo.

Including EIB will also help co-finance projects with other donors and grants the EU and will support the implementation of various instruments such as the Framework for Investment in the Western Balkans (WBIF) (Framework, 2016) and the Institute for Development and Innovation Enterprise Western Balkans (IZhINBP (Fund, 2016) in this context, the EIB in Kosovo a positive signal to foreign investors and this framework agreement represents a significant opportunity for economic development in Kosovo.

Kosovo must commit to speed up reforms to achieve economic development and the signing of this agreement sets out the basis for good cooperation between the EIB and Kosovo that will support the European perspective of Kosovo.

Besides funds, EIB offers the experience is important in accordance with EU policies and in coordination with counsel technical and financial cooperation, which manages the European Commission through the instrument for Preaccession instrument known as IPA is analyzed above. The EIB has been operating in Kosovo, and is investing in infrastructure projects in Kosovo, also paying special attention to SMEs (Bank E. I., 2016). Another possibility within the possibilities of foreign investment constitutes the beginning of the implementation phase of the SAA in the future. (EU, 2014).

The implementation of the SAA in the future will create a new climate of economic relations between the EU and Kosovo to develop trade and investment, factors crucial to economic restructuring and modernization. Article 96 of the SAA talks for the Promotion and Protection of Investments. This article states that "cooperation between the parties in the field of promotion and protection of investment focuses on the protection of foreign direct investment and will aim to bring about a favorable climate for private investment, both domestic and foreign, which is essential for economic recovery and industrial Kosovo. Specific goals of cooperation will be for Kosovo to improve the legal framework which favors and protects investment." (Kosovo E. U., 2014.).

\section{Conclusions}

Kosovo's economy has suffered from many years of isolation, where Consequently, the domestic economy has remained unstructured, lost and left the market with useless construction workforce. Given the fact that Kosovo is less developed country, may say that foreign investments are very important segment that help economic development in the country hand. Their current flow is of a satisfactory average level, but need new membership are normally carried reforms aimed at attracting investments in different construction sectors as construction, agriculture, tourism etc.

Kosovo still remains the country with relatively more low attraction in the region. There are decreases of 50\% during 2012, this negative climate kontibuojnë are a number of factors. The continuing decline of foreign investments in Kosovo is a result of lack hand investment policy, trade and fiscal policy. Foreign investment in Kosovo who have mainly occurred are followed by the privatization process erroneous Chat Chat Chat harmful policy pursued in the banking sector and as such of course they did not deliver very satisfactory results. The sectors in the country than to help the local economy, but has blocked implementation of the business through membership interest rates to high and severe credit constraints in many construction market. Kosovo's corrupt image in the Western world is extremely negative and the arrival of foreign investors' construction of very timely and will depend on improvements to that our authorities have made in this area. 


\section{References}

Bank, E. I. (2016, 04 03). EIB. Gjetur 04 2016, nga EIB: http://www.eib.org/

Bank, K. C. (2012, ). Annual Report. Prishtine: bqk-kos.org .

Bank, W. (2016, 03 03). Doing Business. 03 2016, Doing Business: http://www.doingbusiness.org/data/exploreeconomies/kosovo

Brewer, T. L. (1993). Government Policies, Market Imperfections, and Foreign Direct Investment. Journal of International Business Studies.

EU, G. o. (2014). Stabilisation and Association Agreement between the European Union and Kosovo. Prishtine: Governance of Kosove \& EU.

Framework, W. B. (2016, 04 06). WBIF. Gjetur 04 05, 2016, nga WBIF: https://www.wbif.eu/

Fund, E. I. (2016, 04 04). eif. Gjetur 04 04, 2016, nga eif: http://www.eif.org/what_we_do/resources/wbedif/

group, w. b. (2016, march). Doing Business. Gjetur 03 03, 2016, nga Doing Business: http://www.doingbusiness.org/data/explore economies/kosovo

Hood, N. and Young, S. (1979). The Economics of Multinational Enterprise. Longman Group Limited.

Kosovo, E. U. (2014.). Stabilisation and Association Agreement between the European Union and Kosovo. Prishtine: Governance of Kosovo \& EU.

Kosovo, G. o. Law on Ratification of the Framework Agreement between the Government of the Republic of Kosovo and the European Investment Bank regulating the activities of the European Bank for Investment in Kosovo. Prishtine: Governance of Kosovo \& EU.

Kosovo, I. 0. (September 2014). Progress Raport of the year 2014 to Europian Comision for Kosovo. Prishtine: Europian Comision for Kosovo.

Moosa, I. A. (2002). Foreign Direct Investment-Theory, Evidence and Practice. New York: Palgrave.

Prime minister, (2011-2014). Action Plan of the Economic Vision of Kosovo 2011-2014. Prishtine: Economic Vision of Kosovo.

Alan M. Rugman and Richard M. Hodgetts. 2003. International Business. Financial Times / Prentice Hall.

Brada, Kuta and Yigit. 2006. The Effects of Transition and Political Instability on Foreign Direct Investment Inflows.

Brewer, T. L. (1993). Government Policies, Market imperfections, and Foreign Direct Investment. Journal of International Business Studies. See f.101-117.

Dimitri G. Demekas. 2005 Foreign Direct Investment in Southeastern Europe.

HOTI Hamdi, Safet Hoxha CONTEST Mustafa: "FDI in Kosovo" international scientific and research journal DISCUSSION, no. 9 January 2013 www.diskutime.org PRINT ISSN 1857-825X, Online ISSN: 1857-8543;

HOTI, Hamdi: "Sources of Econimoc grouth and Sustainable Development" Social Science Research Network (SSRN), on November 2012;

Oliver Wendell Holmes, "The Comon Law", Dover Publications, 1991 (1881);

Hood, N.and Young, S., 1979.The Economics of Multinational Enterprise, Longman Group Limited. 